\title{
SOCIOLOGÍA DE LA LITERATURA
}

\section{Antonio Sánchez Trigueros y otros}

[Grupo de investigación de «Teoría de la literatura y sus aplicaciones» de la Universidad de Granada]

(Madrid: Síntesis, 1996)

El amplio y conflictivo espacio teórico e ideológico en el que se han ido conformando y desarrollando los diversos análisis sociológicos y marxistas estructura, sin duda, uno de los campos más fecundos e interesantes del pensamiento acerca de la literatura ( Cfr., R. Escarpit et alii, Hacia una sociología del hecho literario, Madrid: Edicusa, 1974; A. Sánchez Vázquez, Estética y marxismo, 2 vols., México: Era, 1975 y M. Beltrán, La realidad social, Madrid: Tecnos, 1991), el cual, además, con lo que se acrecienta su dificultad no sólo epistemológica sino sintética, añade a una no muy lejana sospecha metodológica una falta de unidad en los textos, producto, en especial, de su imposible neutralidad histórica y de una doble perspectiva teórica que iría desde la concepción de la Filosofia como teoría del saber científico hasta ubicar esta última dentro de los parámetros de las condiciones naturales de la vida social: « Las diferencias provienen (...) de las problemáticas y 
perspectivas teóricas que construyen objetos de conocimiento diferentes a partir de un dominio real, apostando por una valoración o asepsia crítica, primando el estudio de la literatura como producto social [Taine / Lukács] o como fenómeno de simple circulación social [Escarpit / Silbermann], etc.» (A. Chicharro Chamorro, «La teoría de la crítica sociológica», pp. 387-453, en Teoría de la crítica literaria, Pedro Aullón de Haro (ed.), Madrid: Trotta, 1994, p. 388).

Una esfera del conocimiento literario, por tanto, en la que conviven tanto la mera sociología empírica como los planteamientos marxistas necesitada de sistematización expositiva, puesto que: « La unidad no es algo que, sin embargo, caracterice a esta disciplina (...) La llamada crítica sociológica o sociología de la literatura presentará tantas variedades cuantos conceptos de 'sociedad' y de 'sociología' se manejen por sus cultivadores. Lo que hay de común en todos ellos son las nociones sociológicas fundamentales, o, dicho de otro modo, la problemática característica de esta disciplina: la discusión atañe a cuestiones como las instituciones, o la conciencia colectiva, las claves sociales, las ideologías, etc.» (Sultana Wahnón, Introducción a la historia de las teorías literarias, Granada: Universidad de Granada, 1991, p. 123).

Siendo, pues, las anteriores las complejidades que problematizan una, ya necesaria, homogénea propuesta expositiva, el texto que presenta el Grupo de Investigacion de «Teoría de la literatura y sus aplicaciones» de la Universidad de Granada, consigue armonizar, desde la radicalidad del trabajo científico y desde la metodología que lo construye las diferentes trayectorias, escuelas y variantes de la Sociología de la literatura.

Claridad, agudeza de planteamientos y precisión del objeto a analizar que deja claro en su Introducción, el director del Grupo, el profesor Sánchez Trigueros: « La sociología, es decir, la explicación de la evolución de las sociedades humanas, y en efecto, la Sociología de la literatura, o sea, el conjunto de reflexiones más o menos sistemáticas y metódicas sobre las relaciones entre literatura y Sociedad, son productos de la lucha de clases, y cada una de ellas desde sus respectivos comienzos se ha dividido en dos grandes caminos: la dirección positivista y la dirección materialista histórica. La primera, convencida de que la nueva sociedad burguesa e industrial significaba el encuentro del hombre consigo mismo y el fin de la historia, sólo pretendía alcanzar esa meta y el perfeccionamiento del modelo; la segunda denunciaba el engaño de la unidad social pregonada por la burguesía y constataba el nuevo e irresoluble conflicto de clases» ( Sociología de la literatura, p. 8). 
Efectivamente, el texto recorre y recoge en sus seis capítulos: $E l$ espacio de la sociología literaria (Antonio Chicharro y J. Valles Calatrava); Los clásicos del marxismo (Antonio Sánchez Trigueros y Sultana Wahnón); La crítica sociológica continental (I) (José Valles, Carmen Martínez Romero y Manuel Cáceres Sánchez), La crítica sociológica continental (II) (Francisco Linares Alés y Sultana Wahnón); La crítica materialista anglosajona (M.. Ángeles Grandes Rosales); Una teoría en expansión: la poética social dialógica del Círculo de Bajtín (Domingo Sánchez-Mesa Martínez), de manera ordenada y coherente las coordenadas ideológicas e históricas constitutivas de la Sociología, las bases que los fundamentos del marxismo aportan a lo que Althusser denominó «revolución teórica» y que nutren el origen científico de esta disciplina, para, a continuación, pasar revista a todas las aportaciones europeas que, hasta la actualidad, siguen analizando los conflictos sociales, lejos del escapismo fútil de la sociología burguesa, como una consecuencia de la lucha de clases en sus distintas fases tras la consolidación, a todos los niveles, de la ideologia capitalista.

Frente a las imágenes de «sujeto plano» o de «individualidad libre», propias de la materia ideológica burguesa, en las páginas de Sociología de la literatura, los distintos profesores que atienden los capítulos señalados optan por una objetividad histórica que no es sino una profunda legitimadora del hombre como producto de su configuración en una formación social -nivel ideológico- en la que lo económico funciona siempre como eje determinante. Obra imprescindible, además de su calidad y rigor metodológico — alejados de los meros catálogos asépticos del espíritu hegeliano de los manuales-, Sociología de la literatura es una reflexión, en tiempos de universales asimiladores de pensamiento y de intentos desideologizadores, que consigue resituar, con urgencia, y atendiendo a sus contradicciones, la constitución de la crítica problematizando su objeto.

En fin, y como señalaba L. Althusser, «El marxismo es a la vez una ciencia (el materialismo histórico) y una filosofía (el materialismo dialéctico). El discurso científico y el discurso filosófico, tienen exigencias propias: estilizan palabras del lenguaje cotidiano (...) pero (...) funcionan siempre de un modo distinto a como lo hacen en el lenguaje cotidiano. En el lenguaje teórico las palabras y expresiones funcionan como conceptos teóricos (...) en ellos el sentido de las palabras no está fijado por su uso corriente sino por las relaciones existentes entre los conceptos teóricos en el interior de un sistema (...). La dificultad 